\title{
Вікторія БУЛАВИНЕЦЬ
}

кандидат економічних наук, доцент, Тернопільський національний економічний університет, Тернопіль, Україна, Viktoriabulavynets@gmail.com

ORCID ID: 0000-0001-8169-7331

\section{Наталія КАРПИШИН}

кандидат економічних наук, доцент, Тернопільський національний економічний університет, Тернопіль, Україна, nkarpyshyn@gmail.com

ORCID ID: 0000-0002-5264-1200

\section{ФІНАНСОВИЙ ПОТЕНЦІАИ ТЕРИТОРІАМЬНИХ ГРОМАД: СУЧАСНИЙ СТАН I ПЕРСПЕКТИВИ}

Вступ. В умовах проведення бюджетної децентралізації в Україні органи місцевого самоврядування намагаються ефективно використовувати надані їм повноваження і розкривати фрінансовий потенціал територіальної громади з метою збільшення доходів місцевих бюджетів та підвищення обсягів фрінансування суспільних послуг на місцевому рівні.

Мета - з'ясувати суть фрінансового потенціалу територіальних громад та проаналізувати його сучасний стан у контексті наявних і потенційних джерел фінансових ресурсів, які можуть використовувати органи місцевого самоврядування для реалізації цілей та перспективних завдань.

Методи. Для досягнення поставленої мети використано систему загальнонаукових і спеціальних методів дослідження: аналізу, синтезу та узагальнення - при опрацюванні літературних, статистичних, законодавчих ma Internet-джерел з теми дослідження; методи систематизації й узагальнення даних, порівняння та деталізації - при проведенні аналізу доходів місцевих бюджетів; графрічний, табличний і метод візуалізації для наочного представлення опрацьованих даних; абстрактно-логічний метод - для узагальнення викладеного матеріалу і формулювання висновків.

Результати. З'ясовано, що фрінансовий потенціал територіальної громади - це сукупність наявних і потенційних джерел фрінансових ресурсів, які органи місцевого самоврядування можуть залучати з допомогою бюджетного, інвестиційного, кредитного та грантового механізмів для забезпечення ефективного функціонування громади. Доведено, що у структурі фрінансових ресурсів органів місцевого самоврядування в Україні переважають бюджетні кошти, обсяг яких поступово зростає. Встановлено, що, незважаючи на позитивну динаміку, власні доходи місцевих бюджетів ще не стали основою фрінансової незалежності територіальних громад, а податкові надходження становлять 88\% у структурі власних доходів місцевих бюджетів.

Проаналізовано можливості залучення інвестиційних коштів приватних структур на засадах державно-приватного партнерства як потенційного джерела фрінансових ресурсів

() Вікторія Михайлівна Булавинець, Наталія Іванівна Карпишин, 2019 
територіальних громад. З'ясовано, що джерелами зростання фрінансового потенціалу місцевого самоврядування є кредитні і грантові кошти, які забезпечують фрінансування інфрраструктурних проектів розвитку територіальних громад. Доведено, що специфрічним резервом ресурсного забезпечення територіальних громад є людський капітал, за участі якого відбувається формування, розподіл і використання фрінансових ресурсів громади. Акцентовано увагу на доходах від утилізації побутових відходів як невичерпному фрінансовому ресурсі територіальних громад. Розроблено пропозищії щодо підвищення ефективності використання фрінансового потениіалу територіальних громад на сучасному етапі розвитку.

Перспективи. Предметом подальших наукових розвідок $є$ пошук та поглиблене вивчення шляхів ефективного використання фрінансового потенціалу територіальних громад задля підвищення якості та доступності суспільних послуг на місцевому рівні.

Ключові слова: фрінансовий потенціал, територіальні громади, фрінансові ресурси, інвестиційні ресурси, кредитні ресурси, грантові кошти.

Рuс.: 2, бібл.: 10.

\section{Виктория БУЛАВИНЕЦ}

кандидат экономических наук, доцент, Тернопольский национальный экономический университет, Тернополь, Украина

\section{Наталья КАРПИШИН}

кандидат экономических наук, доцент, Тернопольский национальный экономический университет, Тернополь, Украина

\section{ФИНАНСОВЫЙ ПОТЕНЦИАА ТЕРРИТОРИАМЬНЫХ ОБЩЕСТВ: СОВРЕМЕН- НОЕ СОСТОЯНИЕ И ПЕРСПЕКТИВЫ}

Введение. В условиях проведения бюджетной децентрализации в Украине органы местного самоуправления пытаются эффрективно использовать предоставленные им полномочия и раскрывать фринансовый потенциал территориального общества с целью увеличения доходов местных бюджетов и повышения объемов финансирования общественных услуг на местном уровне.

Цель - выяснить сущность фринансового потенциала территориальных обществ и проанализировать его современное состояние в контексте имеющихся и потенциальных источников фринансовых ресурсов, которые могут использоваться органами местного самоуправления для реализации их целей и перспективных заданий.

Методы. Для достижения поставленной цели использована система общенаучных и специальных методов исследования: анализа, синтеза и обобщения - при проработке литературных, статистических, законодательных и Internet-источников по теме исследования; методы систематизации и обобщения данных, сравнения и детализации при проведении анализа доходов местных бюджетов; графический, табличный и метод визуализации - для наглядного представления проработанных данных; абстрактно логический метод - для обобщения изложенного материала и формулировки выводов.

Результаты. Выяснено, что фринансовый потенциал территориального общества - это совокупность имеющихся и потенциальных источников финансовых ресурсов, которые органы местного самоуправления могут привлекать с помощью бюджетного, инвестиционного, кредитного и грантового механизмов для обеспечения 
эфрфективного функционирования общества. Доказано, что в структуре фринансовых ресурсов органов местного самоуправления в Украине преобладают бюджетные средства, объем которых постепенно растет. Установлено, что, невзирая на позитивную динамику, собственные доходы местных бюджетов еще не стали основой финансовой независимости территориальных обществ, а налоговые поступления составляют 88\% в структуре собственных доходов местных бюджетов.

Проанализированы возможности привлечения инвестиционных средств частных структур на принципах государственно-частного партнерства как потенциального источника фринансовых ресурсов территориальных обществ. Выяснено, что источниками роста фринансового потенциала местного самоуправления являются кредитные и грантовые средства, которые обеспечивают финансирование инфраструктурных проектов развития территориальных обществ. Доказано, что специфическим резервом ресурсного обеспечения территориальных обществ является человеческий капитал, при участии которого происходит формирование, распределение и использование фринансовых ресурсов общества. Акцентировано внимание на доходах от утилизации бытовых отходов как неисчерпаемом финансовом ресурсе территориальных обществ. Разработаны предложения относительно повышения эфрфективности использования финансового потенциала территориальных обществ на современном этапе развития.

Перспективы. Предметом последующих научных разведок является поиск и углубленное изучение путей эффрективного использования финнансового потенциала территориальных обществ ради повышения качества и доступности общественных услуг на местном уровне.

Ключевые слова: финансовый потенциал, территориальные общества, фринансовые ресурсы, инвестиционные ресурсы, кредитные ресурсы, грантовые средства.

\section{Victoria BULAVINETS}

Ph. D., Assoc. Prof., Ternopil National Economic University, Ternopil, Ukraine, Viktoriabulavynets@gmail.com

ORCID ID: 0000-0001-8169-7331

\section{Natalia KARPYSHYN}

Ph. D., Assoc. Prof., Ternopil National Economic University, Ternopil, Ukraine, nkarpyshyn@gmail.com

ORCID ID: 0000-0002-5264-1200

\section{FINANCIAL POTENTIAL OF TERRITORIAL COMMUNITIES: MODERN STATE AND PROSPECTS}

Introduction. In the context of budget decentralization in Ukraine, local governments are trying to make effective use of their powers and financial potential of the territorial community in order to increase local budget revenues and funding of services at the local level.

The purpose is to find out the essence of the financial potential of territorial communities and to analyze its current state in the context of existing and potential sources of financial resources that can be used by local governments for the realization of their goals and perspectives.

Methods. To achieve goal, a system of general scientific and special methods of research was used: analysis, synthesis and generalization - in the processing of literary, statistical, legislative and Internet sources on the topic of research; methods of systematizing and generalizing data, compar- 
ing and detailing were used when conducting analysis of local budget revenues; graphical, tabular and visualization methods were used for visual representation of the processed data; abstract-logical method was used for summarize the material presented and formulate conclusions.

Results. It has been found out that financial potential of a local community is a collection of available and potential sources of financial resources that local governments can attract through budgetary, investment, credit and grant mechanisms to ensure the effective functioning of the community. It is proved that budgetary funds is gradually increasing and prevail in the structure of financial resources of local self-government bodies in Ukraine. Despite the positive dynamics, local budget revenues have not yet become the basis of financial independence of territorial communities, and tax revenues make up $88 \%$ of the structure of local budget own revenues.

Possibilities of attracting private sector investment funds on the basis of public-private partnership as a potential source of financial resources of territorial communities are analyzed. It has been found out that the sources of growth of the financial potential of local self-government are credits and grants, which provide financing for infrastructure projects for the development of territorial communities. It is proved that the specific reserve of resource provision of territorial communities is human capital, with the participation of which the formation, distribution and use of financial resources of the community takes place. Emphasis is placed on revenues from the disposal of municipal waste as an inexhaustible financial resource of territorial communities. Proposals for increasing the efficiency of utilization of the financial potential of territorial communities at the present stage of development have been developed.

Conclusions. The subject of further scientific exploration is the search for and in-depth study of ways to effectively use the financial potential of local communities to improve the quality and accessibility of public services at the local level.

Keywords: financial potential, territorial communities, financial resources, investment resources, credit resources, grant funds.

JEL Classification: $\mathrm{H} 72$.

Постановка проблеми. Основою фрінансової спроможності та економічного зростання територіальних громад в Україні $€$ їх фрінансовий потенціал, який відіграє визначальну роль у забезпеченні суспільного добробуту жителів громади. Надання якісних суспільних послуг - це головне завдання органів місцевого самоврядування, яке реалізується через об'єднання зусиль територіальних громад. Прийняття Закону України “Про добровільне об'єднання територіальних громад” (2014р.) започаткувало процес децентралізації та сприяло розширенню джерел доходів і владних повноважень територіальних громад. Більшість новоутворених громад намагається ефек- тивно використовувати надані можливості і виявляє значну зацікавленість у розширені власного фінансового потенціалу. Адже від того, наскільки ефективно вони зможуть організувати діяльність 3 мобілізації усіх фінансових ресурсів, залежить економічна спроможність територіальної громади і рівень життя її населення.

Аналіз останніх досліджень і публікацій. Вивченням сутності поняття "фрінансовий потенціал" займалися чимало науковців, серед яких варто виокремити А. Буряченко [1], Т. Клименко [2], О. Коломойця [4], С. Онишко [5], О. Тулай [6], С. Шумську [3]. Однак необхідність зміцнення фінансового потенціалу територіальних 
громад обумовлює продовження наукових розвідок у цьому напрямку.

Метою статті $€$ з'ясування сутності фінансового потенціалу територіальних громад та аналіз його сучасного стану у контексті наявних і потенційних джерел фрінансових ресурсів, які можуть використовувати органи місцевого самоврядування для реалізації цілей і перспективних завдань.

Виклад основного матеріалу дослідження. В умовах реформування місцевого самоврядування та децентралізаційних процесів, які відбуваються в Україні і супроводжуються спрямованістю територіальних громад до набуття економічної й адміністративної самостійності, особливу роль відіграє фінансовий потенціал, який є запорукою їх соціально-економічного розвитку.

Термін "фрінансовий потенціал" останнім часом широко використовується науковцями й економістами-практиками, проте й донині нема єдиного трактування. Загалом, поняття “потенціал" тлумачиться як джерела, можливості, засоби, запаси, ресурси, які можуть бути використані для вирішення будь-яких завдань і досягнення певної мети $[1$, с. 87 ; 2, с. $4 ; 3$, с. $56 ; 4$, с. $6 ; 5$, с. 69 ]. Все більше науковців підтримують трактування поняття "потенціал" як певної сукупності економічних, в тому числі і фрінансових ресурсів, і в цьому розумінні до складових потенціалу відносять відповідні трудові, матеріальні, фінансові й інформаційні ресурси. Імпонує підхід О. Тулай, яка вважає, що фінансовий потенціал держави $є$ сукупністю наявних і потенційних фрінансових ресурсів органів державної влади і місцевого самоврядування, суб'єктів господарювання всіх фоорм власності та домогосподарств, що формуються, розподіляються і використовуються за участю людського потенціалу у соціальній сфері, економіці, сфрері охорони навколишнього природного середовища для забезпечення сталого людського розвитку [6, с. 92].
Фінансовий потенціал $€$ передумовою розвитку та динаміки, які досягаються не лише за допомогою наявних ресурсів, а й невикористаних можливостей. Це означає, що ключовим поняттям для фрормулювання змісту категорії "фрінансовий потенціал" $€$ саме "можливість". Однак за своєю суттю фрінансовий потенціал визначається не лише сукупністю фрінансових ресурсів і можливостей, а й їхньою органічною єдністю. Фінансовий потенціал відображає фрінансову спроможність суб'єктів щодо участі у створенні матеріальних благ і наданні послуг та характеризується сукупністю тих засобів, джерел, запасів або фрінансових можливостей, якими володіє суб'єкт і які можуть бути використані для реалізації конкретних цілей та завдань.

Саме тому, з огляду на вищезазначене, під фінансовим потенціалом територіальної громади доцільно вважати сукупність наявних і потенційних джерел фрінансових ресурсів, які органи місцевого самоврядування можуть залучати за допомогою бюджетного, інвестиційного, кредитного та грантового механізмів для забезпечення ефективного функціонування громади. Якщо фінансовий потенціал територіальної громади низький, то це означає, що вона характеризується обмеженими можливостями щодо залучення фрінансових ресурсів.

За допомогою бюджетного механізму відбувається акумуляція коштів у місцевих бюджетах, які $є$ одним із найбільших за обсягом фрінансовим ресурсом, що перебувають у розпорядженні органів місцевого самоврядування. Зокрема, обсяг доходів місцевих бюджетів у 2018 р. вперше перевищив обсяг доходів державного бюджету і становив 52\% консолідованого бюджету України, тоді як у 2014 р. - 42\%.

Співвідношення власних доходів місцевих бюджетів (загального фонду) до обсягу ВВП у 2018 р. становило 7,4\% (у 2014 р. $5,1 \%$ ), у 2019 р. складе $6,8 \%$ (прогноз). 
Абсолютні показники власних доходів місцевих бюджетів України зросли 3 68,6 млрд грн у 2014 р. до 263,4 млрд грн у 2018 р., а за прогнозом на 2019 р. збільшаться до 267 млрд грн, що майже в 4 рази більше ніж у 2014 р. (рис. 1)

Однак, незважаючи на децентралізацію бюджетних ресурсів, власні доходи місцевих бюджетів досі не стали основою фрінансової незалежності місцевого самоврядування, оскільки домінуючу роль в структурі доходів місцевих бюджетів продовжують займати міжбюджетні трансферти - майже 53\% у 2018 р. Згідно з положенями Закону України “Про Державний бюджет на 2019 рік” до місцевих бюджетів передбачено спрямувати загалом 40 різних видів дотацій і субвенцій, з них 29 субвенцій та 5 видів дотацій - із загального фонду державного бюджету [7, с. 11].

У складі власних доходів місцевих бюджетів України більше 88\% займають податкові надходження. Основним податком $€$ податок на доходи фрізичних осіб (ПДФО), надходження від якого становлять майже $60 \%$ усіх податкових надходжень (рис. 2).

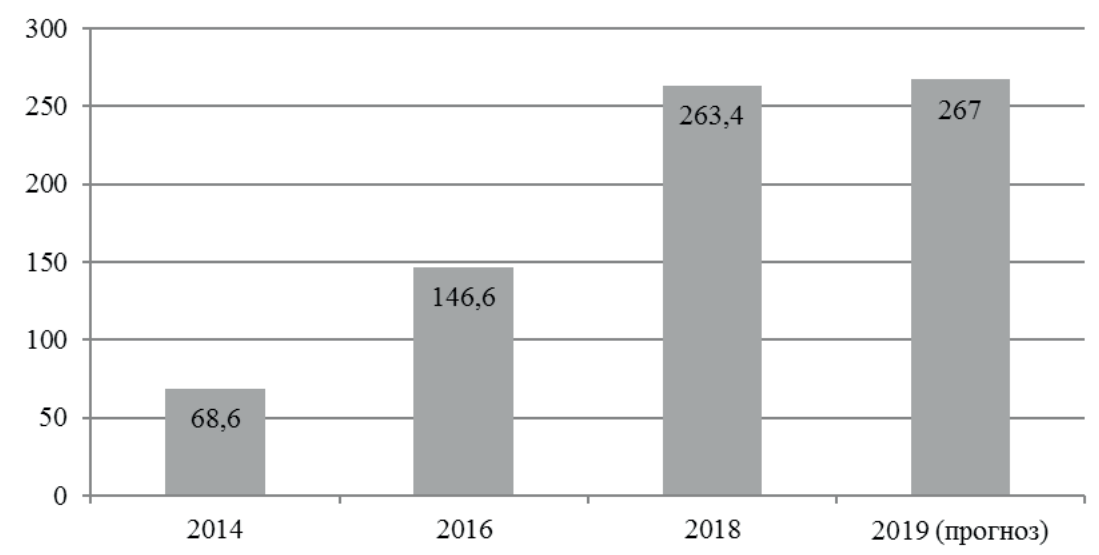

Рис. 1. Динаміка власних доходів місцевих бюджетів України, млрд грн* * Побудовано на основі [7, с. 11; 8; 18].

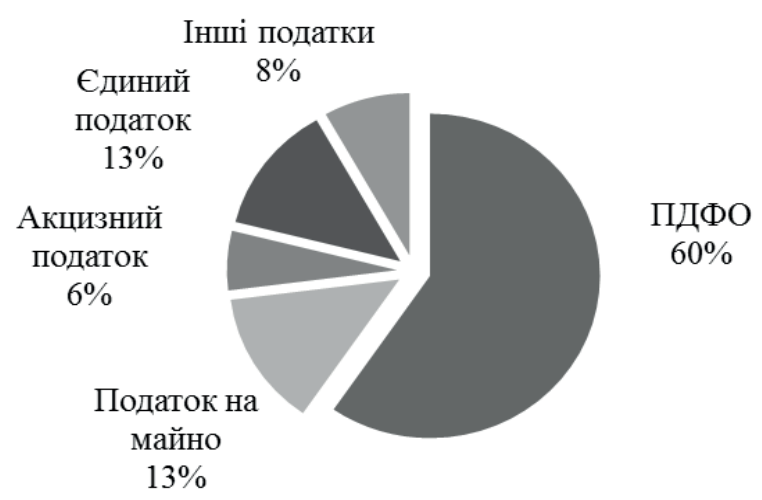

Рис. 2. Структура податкових надходжень місцевих бюджетів України в 2018 р.*

* Побудовано на основі [8]. 
У 2018 р. надходження від ПДФО до місцевих бюджетів України зросли у 2,5 раза, порівняно з 2015 р., що зумовлено, передусім, підвищенням рівня мінімальної заробітної плати. Однак слід зауважити, що не всі можливості щодо збільшення надходжень цього податку використані. Зокрема, наявність "тіньової" зайнятості та нелегальних виплат заробітної плати призводить до недоотримання місцевими бюджетами значної частки ПДФО. Також місцеві бюджети втрачають від неповного декларування фізичними особами своїх доходів. Це $є$ наслідком того, що місцеві органи влади не повною мірою використовують делеговані їм повноваження з контролю за дотриманням законодавства про працю.

Вагому частку в структурі податкових надходжень місцевих бюджетів України займає податок на майно - 13,4\% в 2018 р., який складається з податку на нерухоме майно, відмінне від земельної ділянки, земельного податку і транспортного податку. Однак у його складі надходження від податку на нерухоме майно, відмінне від земельної ділянки, є незначними й у 2018 р. становили лише 3,6 млрд грн, з яких 75\% сплачено юридичними особами.

Важливим джерелом стабільного наповнення місцевих бюджетів України є єдиний податок, основна сума якого надходить від фрізичних осіб-підприємців (близько 68\% його загального обсягу). Надходження єдиного податку залежать як від виваженості фрінансової політики органів місцевого самоврядування в сфері підтримки малого підприємництва, сприяння самозайнятості населення та створення додаткових місць в регіоні, так і від сумлінного ставлення представників малого бізнесу до його сплати.

Суттєво наповнюють місцеві бюджети надходження від акцизного податку. Згідно з нормами бюджетного законодавства, в місцеві бюджети надходить: 13,44\% акцизного податку з виробленого в Україні пального; $13,44 \%$ акцизного податку з ввезеного на митну територію України пального; 100\% акцизного податку з реалізації суб'єктами господарювання роздрібної торгівлі підакцизних товарів (ставка податку - 5\% для пива, алкогольних напоїв, тютюнових виробів, тютюну та промислових замінників тютюну).

Обсяги надходжень цього податку до місцевих бюджетів України щорічно зростають. У 2018 р. у складі акцизного податку переважали податки з реалізації суб'єктами господарювання роздрібної торгівлі підакцизних товарів (46\%) та - з ввезених на митну територію України підакцизних товарів (пальне) (43\%) і $11 \%$ становила частка акцизного податку з вироблених в Україні підакцизних товарів (пальне). Однак на надходження акцизного податку з пального місцеві бюджети можуть розраховувати лише до кінця 2019 р. включно, оскільки 3 1 січня 2021 р. 100\% акцизного податку з пального буде спрямовано до Державного дорожнього фронду, який утворено в складі спеціального фонду Державного бюджету України, для фрінансування робіт, пов'язаних з будівництвом, реконструкцією, ремонтом і утриманням автомобільних доріг загального користування. Щодо акцизного податку з реалізації суб'єктами господарювання роздрібної торгівлі підакцизних товарів, то надходження від нього будуть поступово зростати, оскільки до 2025 р. передбачено підвищення ставок акцизного податку на тютюнові вироби майже у 5 разів.

Незважаючи на значний перелік податкових та інших надходжень до місцевих бюджетів, потенціал бюджетного джерела фрінансових ресурсів територіальних громад задіяний не повністю. Зокрема, поки що органи місцевого самоврядування неповною мірою використовують можливості щодо акумуляції до бюджету коштів від використання земельних ресурсів. Так, до- 
датковим джерелом бюджетних ресурсів можуть бути кошти від оренди та продажу об'єктів комунальної власності (майна та землі), однак значний їх обсяг не обліковується та не використовується. У багатьох ОТГ не сформовані та не оприлюднені на офріційному веб-сайті реєстри комунального майна, яке може бути передане в оренду або продане на конкурсних засадах. Все це призводить до того, що громади не тільки не вміють розпоряджатися своїм майном, а й фактично не знають, що $є$ у їхній власності. Тому місцевим органам влади слід активніше формувати системи реєстрів житлової і нежитлової нерухомості власників на території громади і повною мірою використовувати потенціал податку для наповнення місцевого бюджету.

Потенційними джерелами додаткових надходжень до місцевих бюджетів є також земельний податок та орендна плата за землю. Величина доходів від цих платежів залежить від достовірності інформації щодо кількості земель, які передані в оренду, та розміру земельних ділянок, які перебувають у власності юридичних і фрізичних осіб на території ОТГ. Однак більшість громад сьогодні не мають генеральних планів та технічної документації щодо встановлення їх меж, не забезпечені належними планово-картографічними матеріалами, відповідною землевпорядною та містобудівною документацією. Поряд з цим, не всі громади мають можливість здійснювати зазначені землевпорядні роботи, оскільки їх виконання потребує значних коштів.

Передусім, потребує оновлення процес нормативно-грошової оцінки земель ОТГ, адже документи на землю виготовляли у різні роки, вони мають різний якісний і фрізичний стан, зберігаються здебільшого на паперових носіях у районних управліннях земельних ресурсів. Нині виконавчі органи ОТГ ведуть лише реєстр договорів оренди земельних ділянок, процедура оформлення та реєстрації яких відбувається із затягуванням термінів, що призводить до втрат доходів місцевого бюджету. Однак проведення інвентаризації та нормативної грошової оцінки земель сільськогосподарського призначення, які здані в оренду, дасть змогу збільшити надходження цих платежів до бюджету [9].

Також слід переглянути розмір орендної плати за землю, який нині $€$ вкрай низьким і не відображає реальної вартості земельних паїв. За підрахунками Всеукраїнської асоціації пайовиків розмір орендних платежів за 1 га на рік має бути не нижчим рівня мінімальної заробітної плати. Разом з тим, у зв'язку із затвердженням нового порядку грошової оцінки земель територіальних громад, потребують перегляду розміри орендної плати за раніше укладеними договорами оренди земельних ділянок. Задля збільшення надходжень до місцевих бюджетів також необхідно здійснювати оперативний облік орендарів земельних ділянок і проводити роз'яснювальну роботу з особами, які вчасно не сплатили орендну плату за землю.

Окрім бюджетного джерела ресурсів, для забезпечення потреб територіальних громад можуть бути залучені інвестиційні кошти приватних структур, оскільки більшість ОТГ в Україні на сучасному етапі неспроможні самостійно повною мірою здійснювати фрінансування проектів відновлення і розвитку власної соціальної інфрраструктури. Ефективним інструментом цього процесу може стати державно-приватне партнерство (ДПП).

Механізм партнерських відносин між територіальними громадами та приватним сектором економіки є доволі поширеним явищем у світовій практиці та використовується у розвинених країнах для реалізації інфраструктурних, гуманітарних і приро- 
доохоронних проектів. Зокрема, в Іспанії, Канаді та Великобританії таку практику застосовують у сфері будівництва шкіл, лікарень, автомобільних доріг тощо. У Німеччині приватні інвестиції у наукові дослідження становлять більше 50 млрд євро [10].

Особливістю інвестиційних ресурсів є те, що їх спрямовують на фрінансування соціально-економічного розвитку територій не через бюджет територіальної громади, а безпосередньо на реалізацію проектів. Застосування механізму державно-приватного партнерства дає змогу місцевим органам влади забезпечувати мешканців громади благами колективного користування за рахунок інвестиційних коштів, зберігаючи при цьому контроль за об'єктами інфраструктури. Слід зауважити, що в умовах післякризового розвитку значно зростає інтерес бізнесу до державної підтримки, яка дасть змогу знизити ризики приватних інвестицій та підвищити надійність інвестиційних проектів.

За даними центральних і місцевих органів виконавчої влади в Україні впродовж 1999-2018рр. ініційовано 192 проекти державно-приватного партнерства, з яких лише 66 договорів (34\%) були успішними, що значною мірою спричинено неврегульованістю нормативно-правового середовища. Нині проекти державно-приватного партнерства переважно реалізуються в таких сферах господарської діяльності, як збір, очищення та розподілення води $(47 \%$ від загальної кількості договорів); виробництво, транспортування і постачання тепла (12,1\%); переробка відходів (10,6\%); будівництво та/або експлуатація автострад, доріг, залізниць, злітно-посадкових смуг на аеродромах, мостів, шляхових естакад, тунелів і метрополітенів, морських і річкових портів та їх інфраструктури (10,6\%); управління нерухомістю $(6,1 \%) ;$ виробництво, розподілення та постачання електричної енергії $(4,5 \%)$ [11].
Зарубіжна практика свідчить, що на засадах державно-приватного партнерства доцільно впроваджувати лише 10-15\% найбільш вигідних проектів, які дають можливість оптимізувати розподіл ризиків між державним і приватним партнерами. В Україні застосування ДПП є доцільним, зокрема, у сорері охорони здоров'я, яка перебуває на стадії реформування і потребує будівництва й оснащення критично важливих об'єктів інфрраструктури (онкологічних, діагностичних, діалізних, перинатальних центрів тощо), на які існує платоспроможний попит як з боку держави, так і постійних споживачів. Можливість планування та реалізації проектів ДПП залежить від подальшого удосконалення чинного законодавства та підготовки кваліфікованих кадрів, які володітимуть необхідними знаннями та навичками щодо підготовки і структурування проектів ДПП, проведення аналізу ефективності їх здійснення та моніторингу виконання договорів про державно-приватне партнерство.

За умов верховенства права й ефективного державного управління впродовж щонайменше п'яти наступних років Україна зможе:

- отримати додаткові доходи до державного та місцевих бюджетів в сумі 4,8 млрд дол. США за рахунок концесійних платежів;

- надати збитковим підприємствам можливість згенерувати прибутки на суму до 1,7 млрд дол., частина яких надійде до бюджету у вигляді прямих і непрямих податків;

- скласти гідну конкуренцію як на світовому, так і на європейських ринках за умов якісного відбору проектів, надання гарантій приватним інвесторам, можливості співфрінансування 3 боку МФО, відповідності застосування контрактів державно-приватного партнерства в міжнародній практиці [11]. 
Потенційним джерелом зростання ресурсів фрінансово неспроможних територіальних громад можуть бути залучені кошти. Кредитний механізм економічно розвинених країн охоплює безоблігаційні й облігаційні позики, кредити міжнародних фінансових організацій та місцеві гарантії. У зарубіжній практиці муніципалітети часто вдаються до безоблігаційних позик, які залучаються на засадах строковості, платності та поворотності і, як правило, спрямовуються на створення чи оновлення об'єктів довготривалого користування. Нормативно-правовими актами України також передбачено залучення органами місцевого самоврядування кредитів банківських та інших фрінансових установ. Однак нині за рахунок цього джерела в нашій державі формується менше 5\% доходів місцевих бюджетів, тоді як у країнах ЄС згаданий показник становить близько 10-15\% [12]. Через високий рівень відсоткових ставок за кредитами вітчизняних кредитно-фрінансових установ безоблігаційні позики не користуються широким попитом у територіальних громад і використовуються в основному для фрінансування відносно недорогих та короткострокових проектів.

Обмеженість фінансових ресурсів місцевих бюджетів та використання їх, передусім, на поточні потреби громад та соціальні проекти вимагає більш активного залучення додаткових коштів шляхом емісії та розміщення боргових цінних паперів - муніципальних облігацій, право випуску яких мають лише міські ОТГ.

Облігаційні позики як джерело кредитних ресурсів $€$ інструментом фрінансування важливих місцевих інфраструктурних об'єктів (модернізація та розвиток систем електропостачання, водопостачання, закладів охорони здоров'я та освіти тощо). Інфраструктурні проблеми міст і сучасний кризовий стан житлово-комунальних підприємств
$€$ підставою для значного розширення ринку муніципальних облігацій уже найближчими роками. Однак через недосконалість чинного законодавства України та його неузгодженість з європейськими нормами, виникають проблеми з емісією муніципальних цінних паперів. Згідно з методикою, за якою обраховується державний борг в Україні, борги місцевих органів влади не включаються до загальної суми останнього, тоді як відповідно до методики МВФ борг місцевих органів влади $є$ складовою державного боргу країни. Такі розбіжності у законодавстві призвели до того, що Міністерство фрінансів України відхиляло заяви на дозвіл емісії муніципальних облігацій від місцевих рад через Меморандум про економічну та фрінансову політику, укладений між Україною та МВФ, який передбачав поступове зниження рівня державного боргу. Така ситуація на ринку облігацій місцевих позик пояснюється недостатніми можливостями органів місцевого самоврядування розрахуватися за попередньо випущеними облігаціями [13].

Кредитними ресурсами територіальної громади також можуть бути кредити міжнародних фрінансових організацій, які використовують для задоволення потреб місцевого економічного розвитку. Такі кредити надають за зниженими відсотковими ставками з тривалим терміном користування та на пільгових умовах погашення. Для підтримки розвитку міст в економічно розвинутих країнах широко використовують місцеві гарантії, як механізм залучення кредитних ресурсів суб'єктами публічного або приватного сектору для здійснення діяльності на певній території. У разі неспроможності такого економічного суб'єкта виплатити отриману позику, міська рада бере на себе зобов'язання повного або часткового погашення суми боргу та процентних виплат.

В Україні обсяг та умови здійснення місцевих запозичень від міжнародних фінан- 
сових організацій і надання місцевих гарантій регулюються Міністерством фрінансів України. Згідно з положеннями Бюджетного кодексу України, видатки на обслуговування місцевого боргу не можуть перевищувати 10 відсотків видатків загального фонду місцевого бюджету протягом будь-якого бюджетного періоду [14]. Слід зауважити, що нині роль кредитних ресурсів, як резерву соціально-економічному розвитку ОТГ в Україні, є незначною, оскільки вони становлять лише 0,5-0,8\% сукупних ресурсів громади [15].

В умовах сьогодення важливу роль у фінансуванні інфраструктурних проектів територіальних громад в Україні можуть також відігравати грантові ресурси, які надають на безповоротній та безоплатній основі уряди іноземних держав та міжнародні організації у вигляді грантів, технічної допомоги, благодійних внесків і пожертв. Ресурси, які надають донори для забезпечення потреб економічного розвитку багатьох міст та інших територій у країнах, що розвиваються або перебувають на етапі реформування, є міжнародною технічною допомогою.

Гранти міжнародних донорських організацій мають цільове призначення та, як і міжнародна технічна допомога, можуть надаватися у формі майна, робіт чи послуг, а також фрінансових ресурсів. В Україні, де доступ до інших джерел $є$ вкрай обмеженим, гранти можуть мати вирішальне значення у реалізації різноманітних проектів у сорері місцевого розвитку та виконувати супровідну і підтримуючу функції. Однак отримання коштів з цього джерела вимагає наявності конкурентоспроможного проекту, який міг би бути профінансованим грантодавцем, та його відповідності стратегічному плану соціально-економічного розвитку об'єднаної територіальної громади. Для розробки таких грантових заявок і проектів необхідні спеціально підготовлені фахівці, яких сьогодні в органах місцевого самоврядування обмаль.

Оскільки децентралізаційні процеси в Україні вимагають розширення джерел фінансових ресурсів територіальних громад, то варто звернути увагу на такий невичерпний ресурс, як доходи від утилізації побутових відходів. Щороку в Україні з'являється біля 15 млн тонн твердих побутових відходів, котрі викидають в атмосферне повітря небезпечні токсичні сполуки. Однак, за розрахунками компанії TIC Еко, з однієї тонни побутових відходів можна отримувати 140-280 кубічних метрів біогазу. За даними попередніх розрахунків, на всіх українських смітниках і фермах біогазу вистачить, щоб покрити 10\% річної потреби країни в газі. Нині Україна споживає 75 млрд куб. м природного газу, з яких 55 млрд - імпортне паливо. Водночас потенціал видобутку біогазу становить 7 млрд куб. м на рік [16]. Проте біогазовий сектор України розвивається повільніше, ніж у Європі, оскільки відсутній попит на невеликі установки, обслуговування яких доволі дороге. Згідно з програмами Євросоюзу "Місцевий розвиток, орієнтований на громаду", передбачено спрямування коштів на реалізацію в Україні проектів із енергозбереження, зокрема, запуск малих біогазових установок (на один-два десятки осель, школу чи інший комунальний заклад). Однак досі жодна територіальна громада не зацікавилася таким проектом. Хоча у найближчі чотири роки Україна могла б замінити біогазом один мільярд кубометрів імпортного блакитного палива.

Нестача власних ресурсів задля вирішення поточних проблем розвитку ОТГ може бути також компенсована значними можливостями, які відкривають Програми у рамках Європейського інструменту сусідства (ЄIC) та інших фрінансових інструментів Європейського Союзу. Сьогодні частина прикордонних ОТГ уже реалізовують про- 
екти у рамках Програм транскордонного співробітництва ЄIC. Такі проекти зорієнтовані на розвиток медицини, розбудову дорожньої інфраструктури, забезпечення екологічної безпеки, покращення рекреації, підтримку культури та покращення якості державного управління. Перспективними проектами, що можуть бути реалізованими спільно із суміжними прикордонними територіями сусідніх європейських країн, є: розвиток дошкільної освіти, культури (зокрема, популяризація місцевої історико-культурної спадщини), мистецтва, медицини, спорту, туризму; належне поводження з твердими побутовими відходами; розвиток прикордонної інфраструктури (зокрема, відкриття нових пунктів пропуску); впровадження спільних бізнес-проектів та обмін досвідом. Реалізація зазначених проектів в Україні сприятиме зростанню фінансової самостійності багатьох територіальних громад.

Існує думка, що розвиток територіальної громади базується лише на використанні земельних і фрінансових ресурсів місцевих бюджетів. У переважній більшості громад відсутнє розуміння значення людського капіталу як ресурсу, який забезпечує економічний розвиток території. Значна частка населення у працездатному віці віддає перевагу працевлаштуванню за кордоном. У сформованих ОТГ це ставить під загрозу досягнення цілей децентралізації, результативність якої, на нашу думку, в першу чергу залежить від рівня розвитку людського капіталу.

Професіоналізм, значний інноваційний потенціал, стратегічне мислення та творчий підхід, знання у сфері організаційного та фрінансового менеджменту, комунікативні навички фахівців можуть стати, за інших рівних умов, визначальним нематеріальним ресурсом, який здатен забезпечити високий рівень розвитку територіальної громади. Отож, людський капітал, як основа для фор- мування управлінського персоналу території, $€$ специфічним резервом ресурсного забезпечення, що безпосередньо впливає на зростання фінансових ресурсів територіальних громад. Нинішня недосконала система фінансового управління та відсутність стратегічного бачення розвитку громад призводить до неефективного управління наявними ресурсами, а також створює можливості для непрозорої діяльності, що породжує корупційні ризики. Поряд з цим, в окремих громадах видатки на оплату праці управлінського персоналу становлять до $30 \%$ доходів бюджету, що є економічно невиправданим. Тому ще одним значимим резервом зростання фрінансового потенціалу територіальних громад $€$ створення умов для розвитку управлінських кадрів.

Висновки. Отже, кожна територіальна громада має власний фінансовий потенціал і може залучати потенційні джерела фінансових ресурсів. Максимально розкрити і використати фінансовий потенціал територіальних громад в сучасних умовах можна, якщо:

- здійснити перегляд договорів оренди на використання земельних ресурсів і користування цілісними майновими комплексами, з метою визначення реальної ставки орендної плати;

- використовувати диференційований підхід при встановленні ставок єдиного податку за видами діяльності, які відповідали б річним доходам підприємців, що позитивно вплине на підприємницьке середовище в громаді і частково вирішить проблему ухилення від сплати єдиного податку;

- створити контролюючий орган із дотримання законодавства про працю 3 метою виявлення випадків тіньової зайнятості і нелегальної виплати заробітної плати, що призведе до зростання ПДФО в доходах місцевих бюджетів; 
- забезпечити належний контроль 3 боку органів місцевої влади за своєчасною реєстрацією договорів оренди земельних паїв, які перебувають у власності фрізичних осіб, орендарямиплатниками єдиного податку четвертої групи, що сприятиме зростанню надходжень до місцевих бюджетів.

- сорормувати сприятливе середовище для залучення приватного капіталу й активізувати потенціал механізму державно-приватного партнерства на місцевому рівні;

- налагодити комунікації місцевого самоврядування з бізнесом та громадськістю шляхом запровадження відкритої регуляторної платформи, що позитивно вплине на інвестиційну привабливість регіону й розвиток малого та середнього бізнесу.

- створити позитивний імідж та привабливу "кредитну" історію територіальної громади;

- перетворити ринок муніципальних цінних паперів на інструмент ресурсного забезпечення територіальної громади через підвищення їх вигідності, дохідності та рівня ліквідності;

- налагодити ефективну співпрацю із зарубіжними та національними інституціями (грантодавцями) задля набуття досвіду і навичок підготовки проектних заявок та необхідних документів;

- акцентувати увагу на фрормуванні управлінського персоналу території як специфрічного резерву формування ресурсного забезпечення, що безпосередньо впливає на зростання фінансових ресурсів територіальних громад;

- зміцнювати фрінансовий потенціал територіальних громад через використання такого невичерпного ресурсу, як доходи від утилізації побутових відходів.
Таким чином, органи місцевого самоврядування, які зацікавлені в розвитку підвищенні якості життя своїх мешканців, мають ефрективно використовувати фрінансовий потенціал територіальної громади шляхом пошуку резервів зростання як обсягів податкових надходжень, так і залучення грантових, кредитних та інвестиційних коштів у бюджет громади. Максимальне використання фрінансових можливостей громади також неможливе без залучення людського капіталу та створення умов для його розвитку.

\section{Список використаних джерел}

1. Буряченко А. Є. Фінансовий потенціал регіонального розвитку : монографрія. Київ : KHEУ. 2013. 342 c.

2. Клименко Т. В. Фінансовий потенціал розвитку регіону : автореф. дис... канд. екон. наук : 08.00.08 - гроші, фрінанси і кредит. Чернігiв. $2014.21 \mathrm{c}$.

3. Шумська С. С. Фінансовий потенціал України: методологія визначення та оцінки. Фінанси України. 2007. № 5. С. 56-57.

4. Коломиец А. Л, Новикова А. М. О соотношении финансового и налогового потенциала в региональном разрезе. Налоговый вестник. 2000. C. 6-9.

5. Онишко С. В. Фінансовий потенціал інноваційного розвитку економіки. Фінанси України. 2003. № 6. С. 67-74.

6. Тулай О. І. Державні фрінанси у забезпеченні сталого людського розвитку : дис. ... д-ра екон. наук : 08.00.08. Тернопіль : ТНЕУ, 2016. С.92

7. Децентралізація влади: порядок денний на середньострокову перспективу. Аналітична доповідь / Жаліло Я. А., Шевченко О. В., Романова В. В. та ін. Національний інститут стратегічних досліджень. Київ, 2019. С. 11.

8. Звіти про виконання місцевих бюджетів Автономної Республіки Крим, областей, міст Києва та Севастополя за 2014-2018 pp. URL : http://www.treasury.gov.ua. 
9. Місцеві бюджети зростають - але резервів ще багато. URL : https://biz.censor.net.ual m3029101.

10. Прихований клондайк: як розкрити потенціал бюджетів об'єднаних територіальних громад. URL : https://voxukraine.org/uk/prihovanijklondajk-yak-rozkriti-potentsial-byudzhetiv-obyednanih-teritorialnih-gromad/.

11. Державно-приватне партнерство: час вчитися на помилках. URL : https: // dt.ua | gazetal issuel 1168.

12. Ресурсне забезпечення об’єднаної територіальної громади та їі маркетинг. URL : https://www.prostir.ua/?library=resursnezabezpechennya-objednanoji-terytorialnoji-hromadyta-jiji-marketynh.

13. Децентралізація влади: як зберегти успішність в умовах нових викликів? URL : $\underline{\text { http:// }}$ www.niss.gov.ua/articles/1131/.

14. Бюджетний кодекс України. URL: https:// zakon.help/law/2456-VI/edition01.01.2018/page8.

15. Об'єднані територіальні громади. Децентралізація. URL : https://decentralization.gov. ua/gromada.

16. Минулого року в Україні збільшилася кількість біоелектростанцій. URL : https:// glavcom.ua/economics/finances/-559102.html.

17. Бюджет України 2018. Статистичний збірник. URL : https://www.mof.gov.ua/uk/ statistichnij-zbirnik.

\section{References}

1. Buriachenko, A. le. (2013). Finansovyi potentsial rehionalnoho rozvytku [Financial potential of regional development]. Kyiv: KNEU [in Ukrainian].

2. Klymenko, T.V. (2014). Finansovyi potentsial rozvytku rehionu [Financial development potential of the region]. (Thesis: 08.00.08). Chernihiv [in Ukrainian].

3. Shumska, S. S. (2007). Finansovyi potentsial Ukrainy: metodolohiia vyznachennia ta otsinky [Financial potential of Ukraine: methodology for determination and evaluation]. Finansy Ukrainy - Finance of Ukraine, 5, 56-57 [in Ukrainian].
4. Kolomiets, A. L, Novikova, A. M. (2000). O sootnoshenii finansovogo i nalogovogo potentsiala $\checkmark$ regionalnom razreze [On the ratio of financial and tax potential in a regional context]. Nalogovyiy vestnik - Tax Bulletin, 6-9 [in Ukrainian].

5. Onyshko, S. V. (2003). Finansovyi potentsial innovatsiinoho rozvytku ekonomiky [Financial potential of innovative economic development]. Finansy Ukrainy - Finance of Ukraine, 6, 67-74 [in Ukrainian].

6. Tulai, O. I. (2016). Derzhavni finansy u zabezpechenni staloho liudskoho rozvytku [Public finances for sustainable human development]. (Thesis: 08.00.08). Ternopil: TNEU [in Ukrainian].

7. Zhalilo, Ya. A., Shevchenko, O. V., Romanova, V. V. (2019). Detsentralizatsiia vlady: poriadok dennyi na serednostrokovu perspektyvu. Analitychna dopovid [Decentralization of power: agenda for the medium term. Analytical report] Natsionalnyi instytut stratehichnykh doslidzhen - National Institute for Strategic Studies. Kyiv [in Ukrainian].

8. Zvity pro vykonannia mistsevykh biudzhetiv Avtonomnoi Respubliky Krym, oblastei, mist Kyieva ta Sevastopolia za 2014-2018 [Reports on implementation of local budgets of the Autonomous Republic of Crimea, regions, cities of Kyiv and Sevastopol for 2014-2018]. Available at: http://www.treasury.gov.ua.

9. Mistsevi biudzhety zrostaiut - ale rezerviv shche bahato [Local budgets are increasing, but there are many more reserves]. Available at: $\underline{\text { htps:// }}$ biz.censor.net.ua/m3029101.

10. Prykhovanyi klondaik: yak rozkryty potentsial biudzhetiv obiednanykh terytorialnykh hromad [The hidden klondike: how to unlock the budgets of united territorial communities]. Available at: https://voxukraine.org/uk/prihovanij-klondajk-yak-rozkriti-potentsial-byudzhetiv-ob-yednanih-teritorialnih-gromad/.

11. Derzhavno-pryvatne partnerstvo: chas vchytysia na pomylkakh [Public-private partnership: it is time to learn from mistakes]. Available at: https: // dt.ua I gazetal issuel 1168.

12. Resursne zabezpechennia obiednanoi terytorialnoi hromady ta yii marketynh [Resource support for the integrated territorial community and 


\section{ФIНАНСОВИЙ МЕХАНІЗМ}

its marketing]. Available at: https://www.prostir. ua/?library=resursne-zabezpechennya-objednanoii-terytorialnoji-hromady-ta-iiji-marketynh.

13. Detsentralizatsiia vlady: yak zberehty uspishnist v umovakh novykh vyklykiv? [Decentralization of power: how to stay successful in the face of new challenges?]. Available at: http://www.niss.gov. ua/articles/1131/.

14. Biudzhetnyi kodeks Ukrainy [Budget Code of Ukraine]. Available at: https://zakon.help/ law/2456-VI/edition01.01.2018/page8.

15. Obiednani terytorialni hromady. Detsentralizatsiia [United territorial communities. Decentralization]. Available at: https://decentralization.gov. ua/gromada.
16. Mynuloho roku v Ukraini zbilshylasia kilkist bioelektrostantsii [Last year, the number of bio power plants in Ukraine increased]. Available at: https:// glavcom.ua/economics/finances/-559102.html.

17. Biudzhet Ukrainy 2018. Statystychnyi zbirnyk [Budget of Ukraine 2018. Statistical collection]. Available at: https://www.mof.gov.ua/uk/ statistichnij-zbirnik.

Стаття надійшла до редакції 5.08.2019. 